\title{
IMPACT OF TARAXEROL IN COMBINATION WITH EXTRACT OF Euphorbia tirucalli PLANT ON BIOLOGICAL PARAMETERS OF Lymnaea acuminata
}

\author{
Saroj CHAUHAN \& Ajay SINGH
}

\begin{abstract}
SUMMARY
The present work was carried out to evaluate the molluscicidal activity of active ingredient Taraxerol with the acetone extract of Euphorbia tirucalli against Lymnaea acuminata snail. The (fecundity, hatchability and survivability) of snail L. acuminata exposed to this extract was studied. The effects of the tested extracts on life-history traits of harmful snail L. acuminata have also been evaluated, and this study also expounds the inhibitory effects of these extracts singly as well as in binary combination (1:1 ratio). It concluded that these herbal products act as a potential source of molluscicides, and that they would also have the advantage of easy availability, low cost, biodegradability and greater acceptance amongst users than synthetic pesticide.
\end{abstract}

KEYWORDS: Lymnaea acuminata; Plant molluscicide; Reproductive activity alteration; Toxicity; Fascioliasis.

\section{INTRODUCTION}

Fascioliasis, a serious infectious parasitic disease infecting domestic ruminants and humans, tops all the zoonotic helminthes worldwide ${ }^{9}$. It is an important disease caused by the liver flukes Fasciola hepatica and Fasciola gigantica, infecting several herbivorous mammalian species, including cattle and sheep etc. Global coupled sourcing of food with changing consumer vogues, including the consumption of raw vegetables and undercooking to retain the natural taste and preserve heat-labile nutrients, has increased the risk of foodborne transmission ${ }^{34}$. According to the World Health Organization ${ }^{32}$ the infection was limited in the past to specific and typical geographical areas (endemiotopes), but is now widespread throughout the world.

No doubt that there is now a need to control the veterinary infection along with the human infection ${ }^{5}$. A better way to tackle the problem of fascioliasis is to destroy the carrier snails and remove an essential link in the life cycle of the flukes. Molluscicide application is the most important method of aquatic snail elimination ${ }^{25}$. Synthetic and natural molluscicides have played a significant role in restricting the population of the snail L. acuminata ${ }^{24}$. The high cost of imported synthetic compounds, along with increasing concern over the possibility of snail resistance to these compounds and their toxicity in non-target organisms, have given a new impetus to the study of plant molluscicides ${ }^{6,19}$. Molluscicides of plant origin have gained greater importance since it is believed that natural products are ecologically and culturally more sound than synthetic ones ${ }^{19}$. The use of such local plants as molluscicides will contribute significantly in reducing the burden of purchasing expensive synthetic molluscicides used in snail control ${ }^{20}$.
The intention of this work is to evaluate the full potential of molluscicidal activity of active compound Taraxerol from plant Codiaeum variegatum and acetone extract of Euphorbia tirucalli singly as well as in binary combination. Study was also done on the reproductive physiology (fecundity, hatchability and survivability) of snail L. acuminata after exposure of the sub-lethal concentrations of these extract.

\section{MATERIALS AND METHODS}

Experimental plants: The stem bark of the plant Codiaeum variegatum (Family: Euphorbiaceae) and Euphorbia tirucalli (Family: Euphorbiaceae) was collected locally from Gorakhpur, India. First of all, stem bark was washed with tap water and then dried in the shade. Then the dried stem bark was made into a powder with the help of a mechanical device.

Extraction of Taraxerol from the stem bark of Codiaeum variegatum plant: Dried powder was subjected to extraction through Soxhlet apparatus with petrol solvent for about 70 hours and after 70 hours extraction, the solvent was evaporated by vacuum pump to obtain the extract in solid form. The solid was warmed with $\mathrm{CHCl}_{3}$ and filtered to remove the $\mathrm{CHCl}_{3}$ insoluble portion. Then the $\mathrm{CHCl}_{3}$ soluble portion was concentrated and chromatographed over a silica gel column, and then diluted with petrol, benzene $(1: 1)$ to give a crude white solid. The solid was warmed with ether and crystallized from $\mathrm{CHCl}_{3}$, methanol (1:3 ratios) to obtain Taraxerol (2 $\mathrm{Kg}$ powder of stem bark of Codiaeum variegatum yield about 1 gram Taraxerol). The IR and NMR data of Taraxerol was compared with data of LEE et al. ${ }^{10}$.

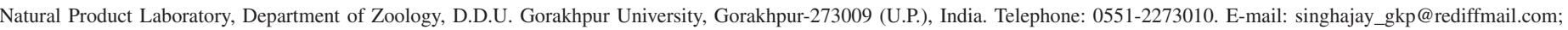
sarojddu@ rediffmail.com 


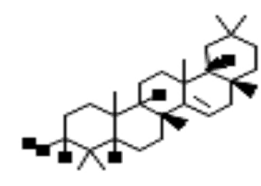

\section{Chemical structure of Taraxerol}

Extraction of compound from Euphorbia tirucalli plant: About 50 grams powder of stem bark was subjected to extraction through Soxhlet apparatus with about $250-300 \mathrm{~mL}$ of acetone for about 40 hours at 20$40{ }^{\circ} \mathrm{C}$. When extraction was completed, a small amount of concentrated solution was obtained. This concentrated solution was filtered and the solvent was evaporated at low temperature by using a vacuum pump until the active compound was dried. The dried compound was used for toxicity experiment.

Experimental animal: L. acuminata $(2.6 \pm 0.3 \mathrm{~cm}$ in shell height $)$ were collected from Ramgarh Lake of Gorakhpur district and acclimatized to laboratory conditions for $72 \mathrm{~h}$. Thirty experimental animals were kept in glass aquaria, containing dechlorinated tap water for L. acuminata snails. Toxicity experiments were performed using the method of SINGH $\&$ AGARWAL $^{21}$. These snails were exposed continuously from $24 \mathrm{~h}$ up to $96 \mathrm{~h}$ to four different concentrations of the extracts. The snails of the control group were kept under similar conditions without any treatment. Mortality was recorded at $24 \mathrm{~h}$ intervals up to $96 \mathrm{~h}$. Lethal concentrations of $\mathrm{LC}_{50}$ values, upper and lower confidence limits (UCL, LCL) and slope values were calculated by computer programme for analysis of bioassay data POLO computer programme of ROBERTSON et al. ${ }^{17}$. The regression coefficient was determined between exposure time and different values of $\mathrm{LC}_{50}$.

Toxicity against non-target organism: A mixed population of ten snails (L. acuminata) and ten fish (C. punctatus) were treated in $6 \mathrm{~L}$ of dechlorinated tap water for $24 \mathrm{~h}$ with $\mathrm{LC}_{90}$ of Taraxerol and acetone extracts of stem bark of E. tirucalli singly and in binary combination.

Reproductive physiology (fecundity, hatchability and survivability): The fecundity, hatchability and survivability experiment were performed according to the method of PRESING ${ }^{15}$. In this experiment, $L$. acuminata snails $(2.6 \pm 0.3 \mathrm{~cm}$ in shell height $)$ were exposed to different sub-lethal concentrations [20\% and $40 \%$ of $\mathrm{LC}_{50}$ (24h)] of Taraxerol and acetone extract of E. tirucalli. For the fecundity test glass aquariums were filled with $5 \mathrm{~L}$ of dechlorinated tap water. Sublethal doses of extracts were mixed in each glass aquarium containing dechlorinated tap water. Ten adult snails were placed in each aquarium at room temperature. Six replicates were used for each set of aquarium. Control groups of snails were kept in an aquarium without treatment. Fresh leaf of the plant Nelumbo nucifera (lotus) was floated in each aquarium.

Lymnaeid snails attached ribbon like egg masses (spawns), contain a variable number of eggs ranging from 10-50 to the back surface of the lotus leaf and inner wall of the aquarium when reproducing. The egg masses produced by the snail in the experiment were removed after every 24 hours up to 96 hours and the number of eggs were counted under the microscope. All the spawns of each group were transferred into separate petri dishes (32 cm diameter x $16 \mathrm{~cm}$ height) containing one liter of dechlorinated tap water for hatching under the same exposure conditions as above and kept at $25 \pm 1^{\circ} \mathrm{C}$ for development of embryo. During the period of embryonic development which lasted from 10 to 13 days, the spawn were examined every day and their growth was studied under a compound microscope in order to follow the progress of development. The survivability of hatched snails was studied for 28 days after hatching.

\section{RESULTS}

\section{Toxicological observation}

Taraxerol: Lethal concentrations (LC) values of Taraxerol against L. acuminata for periods $24 \mathrm{~h}$ to $96 \mathrm{~h}$ are shown in Table 1 . Toxicity of Taraxerol was time as well as dose dependent, and there was a significant negative correlation between LC values and exposure periods, LC value decreases as exposure periods increases from $24 \mathrm{~h}$ to $96 \mathrm{~h}$ (Table 1).

Acetone extract: LC values of compounds extracted through acetone solvent from plant Euphorbia tirucalli stem bark against L. acuminata for periods $24 \mathrm{~h}$ to $96 \mathrm{~h}$ are shown in Table 2 . Toxicity of acetone extract of E. tirucalli stem bark was time as well as concentration dependent, and there was a significant negative correlation between $\mathrm{LC}$ values and exposure periods, $\mathrm{LC}$ value decreases as exposure periods increase from $24 \mathrm{~h}$ to $96 \mathrm{~h}$ (Table 2 ).

Taraxerol+Acetone extracts of stem bark of Euphorbia tirucalli in binary combination (1:1 ratio): Table 3 shows the Lethal concentration values of the effect of combined extracts of Taraxerol+Acetone extracts of stem bark of E. tirucalli (1:1 ratios) against $L$. acuminata for periods ranging from $24 \mathrm{~h}$ to $96 \mathrm{~h}$, LC value decreases as exposure periods increase from $24 \mathrm{~h}$ to $96 \mathrm{~h}$ (Table 3 ).

Regression coefficient showed that there was a significant $(p<0.05)$ negative correlation between exposure time and different LC values. There was no mortality in the control group in each set of experiments (Tables 1, 2, 3).

Biological parameters of snails: Treatment of snails with sub-lethal doses $\left(20 \%\right.$ and $40 \%$ of LC $_{50}$ of $24 \mathrm{~h}$ ) of Taraxerol, Acetone extract of E. tirucalli stem bark individually and Taraxerol+Acetone extracts of Euphorbia tirucalli stem bark in binary combination (1:1 ratios), fecundity, hatchability and survivability was reduced (Table 4).

\section{DISCUSSION}

This study reveals that the active compound Taraxerol when isolated from C. variegatum and acetone extract of E. tirucalli both individually or in combination shows elevated molluscicidal activity. Toxicity data shows that the Taraxerol and acetone extract of E. tirucalli showed a significant positive correlation between concentration and mortality. The concentration dependent response of the snail could be due to several factors, such as rate of penetration, slope, variability and maximal effects of active moieties ${ }^{8}$. Toxicity of these extracts was increased 9.51 times in $24 \mathrm{~h}$ when mixed in a 1:1 ratio rather than individual treatment of acetone extract of E. tirucalli. Toxicity data also showed a significant positive correlation between the mortality of snail and exposure periods and it is due to several factors, which may be acting separately or conjointly, as uptake of active moiety of plant extracts could be time dependent, which 
Table1

Molluscicidal activity of Taraxerol on Lymnaea acuminata snails at different time intervals

\begin{tabular}{|c|c|c|c|c|c|}
\hline Exposure periods & $\begin{array}{c}\text { Effective dose } \\
(\mathrm{mg} / \mathrm{L})\end{array}$ & $\begin{array}{c}\text { Confidence limits (mg/L) } \\
\text { (LCL-UCL) }\end{array}$ & Slope value & 't' ratio & Heterogeneity \\
\hline \multirow[t]{3}{*}{$24 \mathrm{~h}$} & $\mathrm{LC}_{10}=0.57$ & $0.21-0.79$ & $3.23 \pm 0.91$ & 6.35 & 0.05 \\
\hline & $\mathrm{LC}_{50}=1.44$ & $1.21-1.90$ & & & \\
\hline & $\mathrm{LC}_{90}=3.59$ & $2.42-13.45$ & & & \\
\hline \multirow[t]{3}{*}{$48 \mathrm{~h}$} & $\mathrm{LC}_{10}=0.46$ & $0.16-0.65$ & $3.56 \pm 0.91$ & 4.56 & 0.01 \\
\hline & $\mathrm{LC}_{50}=1.05$ & $0.82-1.22$ & & & \\
\hline & $\mathrm{LC}_{90}=2.41$ & $1.85-4.97$ & & & \\
\hline \multirow[t]{3}{*}{$72 \mathrm{~h}$} & $\mathrm{LC}_{10}=0.44$ & $0.17-0.62$ & $3.82 \pm 0.93$ & 4.25 & 0.08 \\
\hline & $\mathrm{LC}_{50}=0.95$ & $0.72-1.11$ & & & \\
\hline & $\mathrm{LC}_{90}=2.06$ & $1.66-3.58$ & & & \\
\hline \multirow[t]{3}{*}{$96 h$} & $\mathrm{LC}_{10}=0.38$ & $0.13-0.55$ & $4.15 \pm 1.03$ & 5.37 & 0.14 \\
\hline & $\mathrm{LC}_{50}=0.78$ & $0.51-0.92$ & & & \\
\hline & $\mathrm{LC}_{90}=1.58$ & $1.34-2.32$ & & & \\
\hline
\end{tabular}

Batches of thirty snails were exposed to four different concentrations of the extract. Concentrations given are the final concentration (w/v) in the aquarium water containing dechlorinated tap water. LCL-Lower confidence limit; UCL-Upper confidence limit.

Table 2

Molluscicidal activity of acetone extracts of Euphorbia tirucalli stem bark on Lymnaea acuminata snails at different time intervals

\begin{tabular}{|c|c|c|c|c|c|}
\hline Exposure periods & $\begin{array}{l}\text { Effective dose } \\
\quad(\mathrm{mg} / \mathrm{L})\end{array}$ & $\begin{array}{l}\text { Confidence limits }(\mathrm{mg} / \mathrm{L}) \\
\text { LCL-UCL }\end{array}$ & Slope value & 't' ratio & Heterogeneity \\
\hline \multirow[t]{3}{*}{$24 \mathrm{~h}$} & $\mathrm{LC}_{10}=03.47$ & $1.15-5.34$ & $2.34 \pm 0.56$ & 4.17 & 0.22 \\
\hline & $\mathrm{LC}_{50}=12.27$ & $9.58-16.29$ & & & \\
\hline & $\mathrm{LC}_{90}=43.31$ & $27.20-145.55$ & & & \\
\hline \multirow[t]{3}{*}{$48 \mathrm{~h}$} & $\mathrm{LC}_{10}=02.43$ & $0.73-3.97$ & $2.45 \pm 0.55$ & 4.42 & 0.39 \\
\hline & $\mathrm{LC}_{50}=08.09$ & $5.66-10.15$ & & & \\
\hline & $\mathrm{LC}_{90}=26.88$ & $19.03-59.87$ & & & \\
\hline \multirow[t]{3}{*}{$72 \mathrm{~h}$} & $\mathrm{LC}_{10}=02.23$ & $0.70-3.62$ & $2.64 \pm 0.57$ & 4.59 & 0.73 \\
\hline & $\mathrm{LC}_{50}=06.81$ & $4.57-8.57$ & & & \\
\hline & $\mathrm{LC}_{90}=20.85$ & $15.61-38.63$ & & & \\
\hline \multirow[t]{3}{*}{$96 \mathrm{~h}$} & $\mathrm{LC}_{10}=01.95$ & $0.59-3.23$ & $2.81 \pm 0.61$ & 4.59 & 0.33 \\
\hline & $\mathrm{LC}_{50}=05.58$ & $3.47-7.14$ & & & \\
\hline & $\mathrm{LC}_{90}=15.91$ & $12.38-25.94$ & & & \\
\hline
\end{tabular}

Details are given in Table 1

leads to a progressive increase in the titer of the active moiety and its effect in the snail's body ${ }^{21-23}$. Stability of active moiety of pesticides in the environment and the rate of their detoxification in an animal body also affect the mortality and exposure period relationship ${ }^{12}$.

Statistical analysis of the data on toxicity brings out several important points. The $\chi^{2}$ test for goodness of fit demonstrated that the mortality counts were not found to be significantly heterogeneous and other variables e.g. resistance etc do not significantly affect the $\mathrm{LC}_{50}$ values, as these were found to lie within the $95 \%$ confidence limits. The regression coefficient showed that there was a significant $(p<0.05)$ negative correlation between exposure time and different LC values. The dose mortality graph exhibits steep slope values. The steepness of the slope line indicates that there is a large increase in the mortality of vectors population with a relatively small increase in the toxicant.

Reproduction is the single most important function in the life cycle of an organism. Successful reproduction determines fitness of organisms. 
CHAUHAN, S. \& SINGH, A. - Impact of Taraxerol in combination with extract of Euphorbia tirucalli plant on biological parameters of Lymnaea acuminata. Rev. Inst. Med. Trop. Sao Paulo, 53(5): 265-70, 2011.

Table3

Molluscicidal activity of Taraxerol + Acetone extract of stem bark of Euphorbia tirucalli (1:1 ratios) on Lymnaea acuminata snails at different time intervals

\begin{tabular}{|c|c|c|c|c|c|}
\hline Exposure periods & $\begin{array}{c}\text { Effective dose } \\
(\mathrm{mg} / \mathrm{L})\end{array}$ & $\begin{array}{l}\text { Confidence limits }(\mathrm{mg} / \mathrm{L}) \\
\text { LCL-UCL }\end{array}$ & Slope value & 't' ratio & Heterogeneity \\
\hline \multirow[t]{3}{*}{$24 \mathrm{~h}$} & $\mathrm{LC}_{10}=0.74$ & $0.46-0.87$ & $5.31 \pm 1.42$ & 5.45 & 0.01 \\
\hline & $\mathrm{LC}_{50}=1.29$ & $1.16-1.62$ & & & \\
\hline & $\mathrm{LC}_{90}=2.26$ & $1.74-5.05$ & & & \\
\hline \multirow[t]{3}{*}{$48 \mathrm{~h}$} & $\mathrm{LC}_{10}=0.57$ & $0.25-0.73$ & $4.66 \pm 1.33$ & 5.13 & 0.01 \\
\hline & $\mathrm{LC}_{50}=1.09$ & $0.95-1.25$ & & & \\
\hline & $\mathrm{LC}_{90}=2.05$ & $1.60-4.74$ & & & \\
\hline \multirow[t]{3}{*}{$72 \mathrm{~h}$} & $\mathrm{LC}_{10}=0.51$ & $0.34-0.70$ & $6.11 \pm 1.41$ & 4.36 & 0.43 \\
\hline & $\mathrm{LC}_{50}=0.92$ & $0.79-1.01$ & & & \\
\hline & $\mathrm{LC}_{90}=1.50$ & $1.31-2.08$ & & & \\
\hline \multirow[t]{3}{*}{$96 \mathrm{~h}$} & $\mathrm{LC}_{10}=0.42$ & $0.28-0.65$ & $6.12 \pm 1.46$ & 5.70 & 0.03 \\
\hline & $\mathrm{LC}_{50}=0.85$ & $0.68-0.94$ & & & \\
\hline & $\mathrm{LC}_{90}=1.37$ & $1.21-1.83$ & & & \\
\hline
\end{tabular}

Details are given in Table 1.

Table 4

Number of laid eggs, egg masses, duration of hatching, hatched eggs, and survivability of hatched young snails (hatchlings) after treatment with $20 \%$ and $40 \%$ of $\mathrm{LC}_{50}(24 \mathrm{~h})$ of Taraxerol, Acetone extract of E. tirucalli stem bark and Taraxerol+Acetone extracts of stem bark of $E$. tirucalli in binary combination (1:1 ratios) against freshwater snails, Lymnaea acuminata respectively

\begin{tabular}{|c|c|c|c|c|c|c|c|c|c|}
\hline & \multicolumn{3}{|c|}{ Taraxerol } & \multicolumn{3}{|c|}{ Acetone extract of E. tirucalli } & \multicolumn{3}{|c|}{ Taraxerol+Acetone extracts } \\
\hline & Control & $\begin{array}{l}20 \% \text { of } 24 \mathrm{~h} \\
\mathrm{LC}_{50}\end{array}$ & $\begin{array}{l}40 \% \text { of } 24 \mathrm{~h} \\
\mathrm{LC}_{50}\end{array}$ & Control & $\begin{array}{l}20 \% \text { of } 24 \mathrm{~h} \\
\mathrm{LC}_{50}\end{array}$ & $\begin{array}{l}40 \% \text { of } 24 \mathrm{~h} \\
\mathrm{LC}_{50}\end{array}$ & Control & $\begin{array}{l}20 \% \text { of } 24 \mathrm{~h} \\
\mathrm{LC}_{50}\end{array}$ & $\begin{array}{l}40 \% \text { of } 24 \mathrm{~h} \\
\mathrm{LC}_{50}\end{array}$ \\
\hline $\begin{array}{l}\text { No. of laid eggs (after } 96 \mathrm{hrs} \text {. } \\
\text { treatment) }\end{array}$ & $\begin{array}{l}435.6 \pm 0.96 \\
(100)\end{array}$ & $\begin{array}{c}380.5 \pm 0.83^{*} \\
(87)\end{array}$ & $\begin{array}{c}352.3 \pm 0.73 * \\
(80)\end{array}$ & $\begin{array}{c}787.16 \pm 1.03 \\
(100)\end{array}$ & $\begin{array}{c}687.50 \pm 0.83^{*} \\
(87)\end{array}$ & $\begin{array}{c}642.16 \pm 0.65 * \\
(81)\end{array}$ & $\begin{array}{l}670.3 \pm 0.92 \\
(100)\end{array}$ & $\begin{array}{l}613.5 \pm 0.47 * \\
(91)\end{array}$ & $\begin{array}{c}580.5 \pm 0.83^{*} \\
(86)\end{array}$ \\
\hline No. of eggs masses & $12.6 \pm 0.73$ & $11.3 \pm 0.96$ & $9.3 \pm 0.96$ & $10.50 \pm 0.83$ & $9.0 \pm 1.05$ & $8.50 \pm 0.83$ & $12.3 \pm 0.96$ & $10.5 \pm 0.83$ & $10.5 \pm 0.83$ \\
\hline $\begin{array}{l}\text { Duration of hatching (in } \\
\text { days) }\end{array}$ & $10-13$ & $12-13$ & $12-13$ & $11-13$ & $12-15$ & $12-15$ & $11-13$ & $12-15$ & $12-15$ \\
\hline No. of hatched eggs & $\begin{array}{c}435.5 \pm 0.83 \\
(100)\end{array}$ & $\begin{array}{c}267.8 \pm 0.66^{*} \\
(77)\end{array}$ & $\begin{array}{c}320.5 \pm 0.833 * \\
(73) \\
\end{array}$ & $\begin{array}{c}784.50 \pm 0.83 \\
(100)\end{array}$ & $\begin{array}{c}660.50 \pm 0.83^{*} \\
(84) \\
\end{array}$ & $\begin{array}{c}618.16 \pm 0.65 * \\
(78)\end{array}$ & $\begin{array}{c}670.1 \pm 1.03 \\
(100)\end{array}$ & $\begin{array}{c}496.8 \pm 0.66^{*} \\
(74) \\
\end{array}$ & $\begin{array}{c}428.8 \pm 0.66^{*} \\
(63)\end{array}$ \\
\hline \multicolumn{10}{|c|}{ Survivability of hatchlings } \\
\hline After 7 days & $\begin{array}{l}431.5 \pm 0.83 \\
\quad(99)\end{array}$ & $\begin{array}{c}194.1 \pm 0.66^{* * *} \\
(72)\end{array}$ & $\begin{array}{c}218.5 \pm 0.83 * * \\
(68)\end{array}$ & $\begin{array}{l}782.50 \pm 0.83 \\
(99)\end{array}$ & $\begin{array}{c}534.50 \pm 0.83^{* *} \\
(80)\end{array}$ & $\begin{array}{c}* 466.16 \pm 0.65 * * \\
(75)\end{array}$ & $\begin{array}{l}669.8 \pm 0.77 \\
\quad(99)\end{array}$ & $\begin{array}{c}327.5 \pm 0.83^{* *} \\
(65)\end{array}$ & $\begin{array}{c}253.5 \pm 0.83^{* *} \\
(59)\end{array}$ \\
\hline After 14 days & $\begin{array}{l}429.6 \pm 0.96 \\
\quad(98)\end{array}$ & $\begin{array}{l}181.1 \pm 0.83 * * \\
(67)\end{array}$ & $\begin{array}{l}200.5 \pm 0.83 * * \\
(62)\end{array}$ & $\begin{array}{c}781.66 \pm 0.73 \\
(99)\end{array}$ & $\begin{array}{l}474.50 \pm 0.83^{* *} \\
(71)\end{array}$ & $\begin{array}{c}* 421.50 \pm 0.83 * * \\
(68)\end{array}$ & $\begin{array}{l}665.5 \pm 0.83 \\
\quad(99)\end{array}$ & $\begin{array}{c}225.0 \pm 0.63 * * \\
(45)\end{array}$ & $\begin{array}{c}187.5 \pm 0.83^{* *} \\
(43)\end{array}$ \\
\hline After 21days & $\begin{array}{l}429.5 \pm 0.83 \\
\quad(98)\end{array}$ & $\begin{array}{l}182.5 \pm 0.83 * * \\
(53)\end{array}$ & $\begin{array}{c}154.3 \pm 0.96 * * \\
(48)\end{array}$ & $\begin{array}{c}777.50 \pm 0.83 \\
(99)\end{array}$ & $\begin{array}{c}363.66 \pm 0.96^{* *} \\
(55)\end{array}$ & $\begin{array}{c}* 270.50 \pm 0.83 * * \\
(43)\end{array}$ & $\begin{array}{l}664.1 \pm 1.24 \\
(99)\end{array}$ & $\begin{array}{c}153.8 \pm 0.66 * * \\
(30)\end{array}$ & $\begin{array}{c}43.5 \pm 0.83^{* *} \\
(10)\end{array}$ \\
\hline After 28 days & $\begin{array}{c}428.5 \pm 0.83 \\
(98)\end{array}$ & $\begin{array}{c}67.8 \pm 0.66^{* * *} \\
(20)\end{array}$ & $\begin{array}{c}43.5 \pm 0.83 * * \\
(13)\end{array}$ & $\begin{array}{c}776.00 \pm 0.63 \\
(98)\end{array}$ & $\begin{array}{c}230.66 \pm 0.96 * * \\
(34)\end{array}$ & $\begin{array}{c}* 177.16 \pm 1.03 * * \\
(28)\end{array}$ & $\begin{array}{c}661.5 \pm 1.22 \\
(98)\end{array}$ & $\begin{array}{c}18.5 \pm 0.83^{* *} \\
(3)\end{array}$ & - \\
\hline
\end{tabular}

The inability of an organism to complete any one of the reproductive process severely reduces its lifetime reproductive success. Disruption in the reproduction will ultimately affect the abundance and distribution of animals ${ }^{33}$. It was also obvious from developmental studies that these plant products do not kill the snails but significantly alter the reproductive physiology of the freshwater harmful snail L. acuminata also, hence it reduces the fecundity, hatchability and survivability of the snail in a dose dependent manner. Reduction in the fecundity was due to intoxication of the parent snail or to the transfer of these plant extracts from the aquatic environment to the egg masses and to the eggs; similar trends in results 
were also observed by COEURDASSIER et al. ${ }^{4}$. It may also be due to the fact that these plant products probably affected the ovulation hormone in the caudo-dorsal cells in the brain of the snail L. acuminata ${ }^{18}$. The lethal concentrations $\left(\mathrm{LC}_{50}\right.$ and $\left.\mathrm{LC}_{90}\right)$ of nicotinanilide and niclosamide are toxic against different stages of the freshwater snail Lymnaea luteola i. e. eggs, immature and adults ${ }^{26}$. The reproductive capacity of $B$. alexandrina is reduced when it was exposed to Allium sativum, A. cepa, and Atriplex halimus $^{11,30}$.

The hatchability of eggs was also significantly decreased after exposure to Taraxerol and acetone extract of E. tirucalli than the control group and it may be due to the fact that these plant extracts perhaps induce embryonic malformations, delays in embryogenesis and, for most toxic effects, the death of embryos ${ }^{16}$ and hence reduction in hatchability. SUKUMARAN et al. ${ }^{27,28,29}$ also reported the n-butanol extracts of some plant molluscicides like Sapindus trifoliatus, Agave americana, Balanites aegyptica, Jatropha gossypifolia, and Vaccaria pyramidata are as toxic against freshly laid eggs of L. luteola. MOSTAFA \& TANTAWY ${ }^{14}$ also found a significant reduction in the hatchability of egg masses of snail Biomphalaria alexandrina after exposure to Calendula micrantha and Anagallis arvensis plant and reduction in the hatching of the snails, revealing an interference of latex exposure with the reproductive process of B. glabrata $^{13}$.

Similarly, survivability of hatched snails was also decreased and it may be due to plant products affecting the respiratory function of the snails by acting as uncoupler of oxidative phosphorylation at the mitochondrial level ${ }^{1,31}$. The reduction in the growth of treated snails may be due to interference of moluscicides with physiological activities of these snails ${ }^{2,3,7}$.

\section{CONCLUSION}

It can be concluded that snail control can be made by using these herbal products as potential molluscicides, at sublethal doses these compound also affect the normal reproductive physiology of snails by causing disturbances in their reproduction and development in the life cycle, which ultimately reduces the abundance and distribution of ecofriendly snails.

\section{RESUMO}

\section{Impacto do Taraxerol em combinação com o extrato da planta de Euphorbia tirucalli nos parâmetros biológicos da Lymnaea acuminata}

O presente trabalho foi levado a efeito para avaliar a atividade moluscicida do ingrediente ativo Taraxerol junto com o extrato de acetona da Euphorbia tirucalli contra o caramujo Lymnaea acuminata. Foram estudados a fecundidade, o desenvolvimento e sobrevivência do caramujo Lymnaea acuminata exposto a estes extratos.

Os efeitos danosos destes extratos testados na vida do caramujo $L$. acuminata foram também avaliados e este estudo demonstra os efeitos inibidores destes extratos isolados ou em combinação binária (relação 1:1). Concluiu-se que estes produtos vegetais agem como fontes potenciais de moluscicidas e que eles também têm a vantagem de obtenção fácil, baixo custo, biodegradabilidade e maior aceitação entre os usuários do que os pesticidas sintéticos.

\section{ACKNOWLEDGEMENTS}

One of the authors (Saroj Chauhan) is thankful to the Indian Council of Medical Research, New Delhi (59/24/2006/BMS/TRM), for financial assistance during this work.

\section{REFERENCES}

1. Andrews P, Thyssen J, Lorke D. The biology and toxicology of molluscicides, Bayluscide. Pharmacol Ther. 1982;19:245-95.

2. Bakry FA, Ragab FMA, Sakran AMA. Effect of some plant extracts with molluscicidal properties of some biological and physiological parameters of Biomphalaria alexandrina snails. J Egypt Ger Soc Zool. 2002;38:101-11.

3. Cheng TC, Sullivan JT. Mode of interaction and toxicity of copper molluscicides. In Cheng TC, editor. Molluscicides in schistosomiasis control. New York: Academic Press; 1974. p. 89-193.

4. Coeurdassier M, De Vaufleury A, Badot PM. Bioconcentration of cadmium and toxic effects on life-history traits of pond snails (Lymnaea palustris and Lymnaea stagnalis) in laboratory bioassays. Arch Environ Contam Toxicol. 2003;45:102-9.

5. Curtale F, Hassanein YA, Savioli L. Control of human fascioliasis by selective chemotherapy: design, cost and effect of the first public health, school-based intervention implemented in endemic areas of the Nile Delta, Egypt. Trans R Soc Trop Med Hyg. 2005;99:599-609.

6. Duncan J, Sturrock RF. Laboratory evaluation of potential plant molluscicides. In Mott KE, editor. Plant molluscicides. Chichester: Wiley; 1987. p. 251-65.

7. El-Gindy HI, Mohamed AM. Some biological and physiological observations on the effect of repeated application of low concentrations of Bayluscide against Bulinus truncatus and Biomphalaria alexandrina. J Egypt Ger Soc Zool.. 1978;8:75-83.

8. Goodman LS, Gilman AG, Rall TW, Murad F, editors. Goodman and Gilman's The pharmacological basis of therapeutics. $7^{\text {th }}$ ed. New York: Mac Millan; 1985.

9. Haridy FM, Morsy TA, Gawish NI, Antonios TN, Abdel Gawad AG. The potential reservoir role of donkeys and horses in zoonotic fascioliasis in Gharbia Governorate, Egypt. J Egypt Soc Parasitol. 2002;32:561-70.

10. Lee JH, Lee KT, Yang JH, Baek NI, Kim DK. Acetylcholinesterase inhibitors from the twings of Vaccinium oldhami Miquel. Arch Pharm Res. 2004;27:53-6.

11. Mantawy MM. Potential effect of Allium cepa and Allium sativum on hemolymph of Biomphalaria alexandrina, the intermediate host of Schistosoma mansoni. J Egypt Soc Parasitol. 2001;32:271-83.

12. Matsumura F. Toxicology of insecticides. $2^{\text {nd }}$ ed. NewYork: Plenum Press; 1985

13. Mello-Silva CC, Vilar MM, Bezerra JCB, Vasconcellos MC, Pinheiro J, Rodrigues MLA. Reproductive activity alterations on the Biomphalaria glabrata exposed to Euphorbia splendens var. hislopii latex. Mem Inst Oswaldo Cruz. 2007;102: 671-4.

14. Mostafa BB, Tantawy AA. Bioactivity of Anagallis arvensis and Calendula micrantha plants, treated with ammonium nitrate, superphosphate and potassium sulphate fertilizers, on Biomphalaria alexandrina. J Egypt Soc Parasitol 2000;30:929-42.

15. Présing M. Influence of an insecticide, K-Othrine, on the reproduction and mortality of the pond snail (Lymnaea stagnalis L.). Arch Environ Contam Toxicol. 1993;25:38793.

16. Ravera O. Influence of heavy metals on the reproduction and embryonic development of freshwater pulmonates (Gastropoda, Mollusca) and cladocerans (Crustacea, Arthropoda). Comp Biochem Physiol. 1991;100:215-9. 
CHAUHAN, S. \& SINGH, A. - Impact of Taraxerol in combination with extract of Euphorbia tirucalli plant on biological parameters of Lymnaea acuminata. Rev. Inst. Med. Trop. Sao Paulo, 53(5): 265-70, 2011.

17. Robertson JL, Russel RM, Preisler HK, Savin ME. Bioassay with arthropods. Boca Raton: CRC Press; 2007.

18. Roubos EW, Boer HH, Schot LPC. Peptidergic neurons and the control of neuroendocrine activity in the fresh water snail Lymnaea stagnalis. In: Proceedings of the Eighty International Symposium on Neurosecreation; 1981. p. 119-127.

19. Sharma S, Singh T, Vijayvergia R. Molluscicidal activity of some medicinal plants. J Herb Med Toxicol. 2009;3:155-7.

20. Shekhawat NN, Vijayvergia R. Molluscicidal activity of some Indian medicinal plants against the snail Lymnaea acuminata and in the control of fascioliasis. J Herb Med Toxicol. 2010;4:109-12.

21. Singh A, Agarwal RA. Possibility of using latex of euphorbiales for snail control. Sci Total Environ. 1988;77:231-6.

22. Singh A, Singh DK, Agarwal RA. Effect of cypermethrin, mexacarbate and phorate on phospholipid and lipideroxidation in the snail Lymnaea acuminata. Bull Environ Contam Toxicol. 1993;51:68-71.

23. Singh A, Agarwal RA. Effect of cypermethrin on lactate and succinic dehydrogenase and cytochrome oxidase of snail and fish. Bull Environ Contam Toxicol. 1993;51:44552 .

24. Singh K, Singh A, Singh DK. Molluscicidal activity of neem (Azadirachta indica). J Ethnopharmacol. 1996;52:35-40.

25. Souza CP. Molluscicide control of snail vectors of schistosomiasis. Mem Inst Oswaldo Cruz. 1995;90:165-8.

26. Sukumaran D, Parashar BD, Gupta AK, Jeevaratnam K, Prakash S. Molluscicidal effect of nicotinanilide and its intermediate compounds against a freshwater snail Lymnaea luteola, the vector of animal schistosomiasis. Mem Inst Oswaldo Cruz. 2004;99:205-10.
27. Sukumaran D, Parashar BD, Rao KM. Molluscicidal properties of Agave americana and Balanites aegyptica. Int J Pharmacog. 1994:32:232-8.

28. Sukumaran D, Parashar BD, Rao KM. Toxicity of extracts Jatropha gossypifolia and Saponaria saponaria as molluscicide against freshwater snails Lymnaea luteola and Indoplanorbis exustus, the vectors of animal schistosomiasis. Fitoterapia. 1995;66:393-8.

29. Sukumaran D, Parashar BD, Rao KM. Evaluation of some plant molluscicides agains a freshwater snail Lymnaea luteola, the vector of animal schistosomiasis. Pharm Biol. 2002;40:450-5.

30. Tantawy AA. Effect of sub lethal concentrations of Atriplex halimus (Chenopediaceae) on Biomphalaria alexandrina, the snail-vector of Schistosoma mansoni in Egypt. J Egypt Soc Parasitol. 2002;32:297-305.

31. White House MM. Report of salicylanilide as decouplers of oxidative phosphorylation in rat mitochondria. Biochem Pharmacol. 1964;13:319.

32. WHO. Report of the WHO Informal Meeting on use of triclabendazole in fascioliasis control. Geneva: WHO; 2007.

33. Woin P, Brönmark C. Effect of DDT and MCPA (4-Chloro-2-methylethylphenoxyacetic acid) on reproduction of the pond snail, Lymnaea stagnalis L. Bull Environ Contam Toxicol. 1992;48:7-13.

34. Yilmaz H, Godekmerdan A. Human fasciolosis in Van province, Turkey. Acta Trop 2004;92:161-2.

Received: 10 November 2010

Accepted: 22 August 2011 